\title{
EFFECT OF PROFESSIONAL CLEANING AND DENTAL BRUSHING WITH OR WITHOUT FLUORIDATED DENTIFRICE ON ENAMEL REMINERALIZATION
}

\author{
EFEITO DA PROFILAXIA PROFISSIONAL E DA ESCOVAÇÃO COM DENTIFRÍCIO COM \\ OU SEM FLÚOR NA REMINERALIZAÇÃO DO ESMALTE DENTAL
}

\begin{abstract}
Sara Nader MARTA ${ }^{1}$, José Eduardo de Oliveira LIMA², Bernardo Gonzales VONO ${ }^{3}$, Salete Moura Bonifácio da SILVA ${ }^{4}$ Maria Aparecida Andrade Moreira MACHADO ${ }^{5}$, Maria Ligia Gerdullo PIN ${ }^{6}$
\end{abstract}

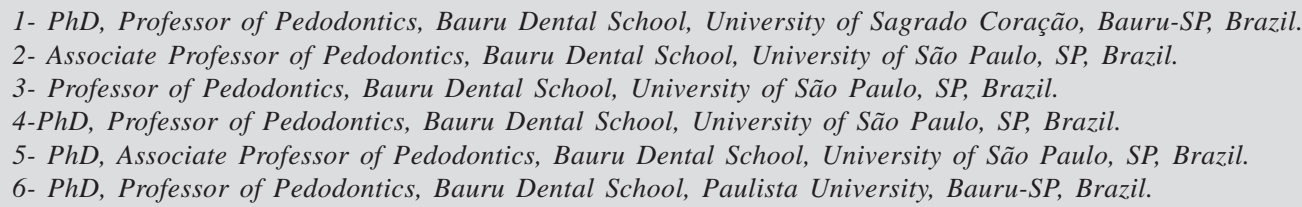

Corresponding address: Sara Nader Marta - R. Professor Gerson Rodrigues 7-28, Vila Universitária - Cep.:17012-535, Bauru, SP, Brazil. Phone: +55 (14) 3234-3549; e-mail: martafilho@uol.com.br

Received: March 03, 2004 - Modification: August 17, 2004 - Accepted: May 30, 2005

\begin{abstract}
A

$\mathrm{n}$ in situ evaluation of the potential rehardening effect of fluoridated and non-fluoridated toothpastes with or without air polishing was conducted. Ten volunteers, using acrylic palatal appliances containing two bovine enamel blocks with artificial carious lesions, took part in this study. Four times a day, after the main meals and at night, the volunteers, in a habitual way, brushed their natural teeth with the dentifrice indicated to the experimental design and after that the appliances were put again into the mouth. They were divided into 4 different groups: G1 - control - non-fluoridated dentifrice; G2 - fluoridated dentifrice; G3 - non-fluoridated dentifrice, but having a previous prophylaxis using air polishing; G4 - fluoridated dentifrice and previous air polishing. The effects of treatments on enamel rehardening were evaluated in the blocks that were assessed by surface microhardness, and the percentage of surface microhardness change (\%reh) was calculated in relation to the baseline values. The results showed that \%reh was higher in the groups with fluoridated dentifrice, and professional prophylaxis did not have an additional effect in the groups of fluoridated dentifrices $(p<0.05)$. The data suggested that, in the absence of fluoride, removal of dental plaque helped to increase the process of enamel rehardening.

Uniterms: Dental enamel; Toothpaste; Dental plaque; Dental prophylaxis.
\end{abstract}

\section{RESUMO}

objetivo deste estudo foi avaliar, in situ, o potencial de remineralizaçaão do dentifrício fluoretado ou não, isoladamente ou associado à profilaxia profissional com jato de bicarbonato de sódio, em esmalte bovino com lesão superficial artificial de cárie. Utilizou-se 80 blocos de esmalte (4X4X2mm), nos quais foram realizadas medidas de microdureza superficial antes e após a desmineralização artificial e após o tratamento, com um penetrador, Knoop carga de 50/7s, para o cálculo do percentual de recuperação de dureza (\%reh). Após as tomadas das 2 medidas de microdureza iniciais (antes e após a desmineralização), os blocos de esmalte foram incluídos em dispositivos intrabucais palatinos (2 blocos/aparelho). Dez jovens voluntários usaram estes dispositivos durante 10 dias com intervalo de 7 dias entre cada fase do experimento (estudo cruzado), realizando higiene bucal habitual (4X/dia, sendo 3 após as refeições e 1 à noite). Estabeleceu-se 4 grupos: G1-controle-escovação com dentifrício sem flúor; G2-escovação com dentifrício fluoretado; G3-antes da instalação do dispositivo realizou-se uma profilaxia com jato de bicarbonato de sódio e escovação com dentifrício sem flúor; G4-profilaxia e dentifrício fluoretado. A análise de variância (ANOVA, $\left.p=1,04 \times 10^{-6}\right)$ e o teste de Student-Newman-Keuls $(\mathrm{p}<0,05)$, realizados para a comparação entre a \%reh dos 4 grupos, indicaram diferença entre todos eles, exceto entre G2 e G4. Concluiu-se que a associação da profilaxia não alterou o desempenho do dentifrício fluoretado na recuperação da dureza superficial do esmalte. Porém, na ausência do flúor a remoção da placa dentária incrementou a recuperação da dureza superficial do esmalte dentário.

Unitermos: Esmalte dentário; Creme dental; Placa dentária; Profilaxia dentária. 


\section{INTRODUCTION}

In its most literal sense, remineralization is the mineral redeposition after loss occurred during or after a caries attack. Remineralization of lesions as a normal occurrence in the oral environment has been shown by several investigators and depends on many factors such as salivary flow rate, buffer capacity, utilization of fluoridated products and mechanical plaque control ${ }^{6,12,16,19,21}$.

The chemical and/or mechanical control of dental plaque plays an important preventive role for reduction of the microorganisms involved in the initiation and progression of dental caries, as well as to allow maintenance of a dynamic balance between the saliva and dental surface ${ }^{12}$.

The process of mineral loss and gain is essentially physicochemical and fluoride may effectively reduce demineralization and/or enhance remineralization ${ }^{6,7}$. The dentifrices are currently considered as the most widespread vehicle for fluoride delivery, but toothbrushing is yet to be recognized as the base of all oral defense mechanisms. Toothbrushing provides the means by which the dentifrice is distributed on a dental surface and disrupts and dislodges dental plaque and oral debris from these surfaces. Yet, the effectiveness of toothbrushing depends on the individual skills and personal motivation for its proper use ${ }^{4}$.

Besides toothbrushing, as a means to promote mechanical plaque control, professional prophylaxis sodium bicarbonate under pressure (air polishing) was demonstrated to provide a significant reduction (27\%) in salivary microorganisms, especially mutans streptococci, for a certain period (30 days) ${ }^{15}$.

Therefore, it is also important to study the association between toothbrushing with fluoridated and non-fluoridated dentifrices and professional prophylaxis using air polishing for mechanical plaque removal, as preventive measures to alter the oral environment. Thus, the purpose of this experimental study was to investigate the influence of such measures on the potential of reestablishment of the surface hardness, as an indicator of remineralization, on demineralized bovine enamel.

\section{MATERIALS AND METHODS}

This study involved a crossover design, performed in four phases of 10 days each. The study design had been previously approved by the Ethics Committee of Bauru Dental School. Ten adult volunteers (mean age: 23 years 5 months old) were included in the study after signing an informed consent term (Regulation n. 196 of the National Health Council, Ministry of Health, Brasilia, DF, March $10^{\text {th }}$ 1996). The individuals were healthy and had no systemic health problems or intraoral carious lesions.

\section{Preparation of the enamel blocks}

Using a diamond bur, eighty enamel blocks (4x4x2mm) were prepared from bovine incisors and sterilized by storage in $2 \%$ formaldehyde solution at $\mathrm{pH} 7.0^{7,23}$ for at least 1 month. The specimens were embedded in the center of acrylic cylinders using clear resin and the surface of the enamel blocks was polished for removal of a layer of $50 \mu \mathrm{m}^{11}$ with a series of silicon carbide sandpaper (600, 800 and 1200 grit). The prepared specimens represented the intact enamel (IE), which were submitted to the microhardness test as described below.

\section{Artificial carious lesions - Demineralization}

Caries lesions were prepared as suggested by White ${ }^{23}$ (1987), by means of immersion of the blocks in $0.05 \mathrm{M}$ lactic acid solution $\mathrm{pH} 5.0$, subsaturated in relation to hydroxyapatite, for a period of 16 hours at $37^{\circ} \mathrm{C}$, thus yielding incipient carious lesions that represented the preliminary stages of subsurface demineralization ${ }^{23}$. These specimens represented the demineralized enamel (DE) and were submitted to the microhardness test, as described below. The blocks were randomly assigned to the four treatment groups.

\section{Intraoral exposure}

The volunteers made use of custom made acrylic palatal appliances $^{7,8}$, containing two bovine enamel blocks each, which were attached to the area of the maxillary first molars at a 1-cm distance from the borders of the plate with a piece of utility wax. A 4.0-mm deep space was created in the acrylic appliance, without leaving any space for plaque accumulation, in order to expose the demineralized surface to the oral environment.

The volunteers were randomly assigned to the treatments with dentifrices with or without prophylaxis using air polishing. The dentifrices were coded as dentifrice A, nonfluoridated, and dentifrice $\mathrm{B}$, containing 1,500ppmF (MFP). All dentifrices contained silica as the abrasive and were prepared by Kolynos do Brasil for this study. Four times a day, after the main meals (3 times) and at night, the volunteers removed their appliances, brushed their natural teeth as usual (with a soft bristles toothbrush) with the dentifrice indicated by the study design, and then returned the appliances to the mouth.

The schedules of toothbrushing were controlled by means of a diary recorded by the volunteers and forwarded to the investigator at completion of each study period. The volunteers were informed that toothbrushing should be performed before placement of the appliance in the oral cavity, and that the tooth block present on the appliance should not be submitted to the action of toothbrushing, so that the artificially demineralized surface layer of enamel was not removed by the mechanical action of the toothbrush, what would mask the results of the treatment established.

The individuals were divided into four different groups: G1 - control (dentifrice A - Dn/F); G2 - dentifrice B (DF); G3 - dentifrice A and previous prophylaxis using air polishing (70 pounds) $(\mathrm{PDn} / \mathrm{F})$, to achieve total removal of dental plaque from the oral environment. The volunteers received only one prophylaxis at the beginning of the experimental period. This prophylaxis was carried out only on the natural 
teeth, without affecting the palatal appliance with the fragment; G4 - dentifrice B and air polishing (70 pounds) (PDF), similar to G3. At completion of each experimental period, the specimens were removed from the palatal devices, representing the treated enamel (TE), and replaced by new fragments. Thus, the effect of the treatments on enamel rehardening was evaluated in the blocks, by means of evaluation of the surface microhardness, as described below. A period of at least 7 days was allowed after each phase to eliminate possible residual effects of the treatments.

The volunteers received instructions to wear the appliances all the time and to remove them during meals, consumption of beverages or toothbrushing. The volunteers used dentifrice A (non-fluoridated) one week before the study and between the phases. The subjects received oral and written information not to use any other antibacterial or fluoridated product, yet to continue drinking the fluoridated water of the city of Bauru $(0.7 \mathrm{ppm})$. Since the study followed a crossover design, with participation of the volunteers in all steps, the subjects did not receive any instructions regarding their daily diet.

\section{Analysis of microhardness}

All blocks of each volunteer in each treatment were evaluated by analysis of the enamel surface microhardness. Previous research has shown that there is a good correlation (0.91) between enamel microhardness and percentage of mineral ${ }^{10}$. Microhardness indentations were made using a M-Testor microhardness tester and a Knoop diamond under 50 -gram load for 7s. Five indentations (intervals of $100 \mu \mathrm{m}$ ) were made on each surface of the individual blocks for determination of the surface microhardness. The surface microhardness of the blocks was analyzed in the sequence of intact enamel (IE), demineralized enamel (DE) and treated enamel (TE) in order to set the recovery rate of the initial hardness (\% rehardening $=\%$ reh), given by ${ }^{14}$ :

$$
\% \text { reh }=\frac{T E-D E}{I E-D E} \times 100
$$

\section{Statistical Analysis}

The surface microhardness values achieved for the fragments on the initial experimental conditions and after demineralization were submitted to analysis of variance (ANOVA), in order to check whether there was similarity between groups as to initial hardness and after induction of the carious lesion. Thus, statistical analysis using the oneway ANOVA test followed by the multiple comparisons test (Student-Newman-Keuls) was applied to detect significant differences between the treatments at $5 \%{ }^{9}$.

\section{RESULTS}

Considering the surface microhardness at onset and after demineralization, the ANOVA test did not reveal differences between groups, with $\mathrm{p}=0.64$ for the initial experimental condition and $\mathrm{p}=0.82$ after demineralization; this condition was required, so that the possible differences found might be assigned to the treatments performed.

The values of enamel surface microhardness (initial, demineralized and final) and the percentage of rehardening are shown in Table 1 . Twenty specimens were employed in each group, since the palatal appliance contained 2 fragments of enamel. The means of the 2 fragments employed for each individual in each experimental group $(n=10)$ was calculated. There was rehardening of the carious lesions in all groups (positive values of the \%reh). The variance analysis (ANOVA, $\mathrm{p}=1.04 \times 10^{-6}$ ) and the Student-NewmanKeuls test $(\mathrm{p}<0.05)$ set to compare \%reh of the 4 groups showed statistically significant differences in all, except for G2 and G4. These data indicated that \% reh was higher in the groups with fluoridated dentifrice (G2 and G4) with the following values: $33.82 \%$; 33.84\%; $24.40 \%$ and $15.40 \%$ for groups G2, G4, G3 and G1, respectively (Table 1). Professional prophylaxis did not have an additional effect only in the groups that made use of fluoridated dentifrice, that is, \%reh G4 = \%reh G2. However, in the absence of fluoride, the removal of dental plaque helped to increase the rehardening process, that is \%reh G3 > \%reh G1 (Table 1).

TABLE 1- Surface microhardness analysis at the initial, demineralized and final periods (means $\pm \mathrm{SE} ; \mathrm{n}=10$ ) and percentage of rehardening (\%reh) in the blocks according to the treatments

\begin{tabular}{|c|c|c|c|c|}
\hline Treatments & & Microhardness & & $\%$ reh \\
\hline & Initial & Demineralized & Final & \\
\hline Dentifrice A (G1) & $242.4 \pm 25.2$ & $91.3 \pm 8.3$ & $113.7 \pm 10.0$ & 15.40 \\
\hline Dentifrice B (G2) & $242.3 \pm 14.2$ & $87.7 \pm 11.5$ & $140.6 \pm 14.6$ & 33.827 \\
\hline $\begin{array}{l}\text { Dentifrice A and } \\
\text { prophylaxis (G3) }\end{array}$ & $229.20 \pm 9.9$ & $91.7 \pm 15.9$ & $127.3 \pm 21.5$ & 24.40 \\
\hline $\begin{array}{l}\text { Dentifrice B and } \\
\text { prophylaxis (G4) }\end{array}$ & $225.9 \pm 7.7$ & $87.8 \pm 13.1$ & $134.4 \pm 10.8$ & 33.84 \\
\hline
\end{tabular}

Groups connected by bars (G2 and G4) did not present statistically significant difference

(Student-Newman-Keuls test ; $p<0.05)$. 


\section{DISCUSSION}

The rationale for keeping the oral environment free of plaque is based on the relationship between dental plaque and oral diseases: dental caries, gingivitis and periodontal disease ${ }^{5}$.

The dental plaque accumulated on the teeth, without mechanical disturbance certainly leads to dental enamel demineralization ${ }^{18,22}$. The $\mathrm{pH}$ is kept low for some time, but returns to the normal level and then the enamel can recover the dissolved mineral (remineralization).

In the present study, enamel rehardening was observed after mechanical removal of dental plaque from the oral environment by toothbrushing with fluoridated or nonfluoridated dentifrices associated or not to professional prophylaxis using air polishing. This was evaluated by means of the change in the enamel surface microhardness (SMH), which is considered a very sensitive method for evaluation of early carious lesions ${ }^{3,24}$, by calculation of the recovery rate of the initial microhardness (\%reh). The test may be applied to a same specimen before and after a certain treatment, allowing indirect quantification of the mineral gain or loss, since previous studies have already demonstrated a relationship between the mineral content of the enamel surface and the length of the indentation produced by the Knoop diamond ${ }^{1,2,3,24}$.

Bovine enamel was used in this study. Previous studies $^{20,23,24}$ considered bovine enamel as an acceptable option to human enamel, since they are more uniform, more porous and present faster demineralization, reducing the time spent with the test and the variability of the substrate response in the study model.

The reduction in the values of surface microhardness in the demineralized status compared to the initial demonstrated the effectiveness of the demineralizing solution employed ${ }^{23}$ in the production of incipient carious lesions. The partial recovery of the surface microhardness, observed on the final status of the study design, revealed the effect of the treatment applied in each study groups, taking into account that the specimens were not submitted to the mechanical action of toothbrushing or air polishing. This care was taken so that the enamel surface softened by the acid would not be mechanically removed, what would mask the real effects of the treatment applied in each study group. Therefore, professional prophylaxis and routine toothbrushing were performed on the natural teeth of subjects to promote alterations in the oral environment that might favor the remineralization process, as evaluated by the percentage of recovery of the surface microhardness (\%reh) of the fragments of bovine teeth placed in the palatal devices.

Concerning the treatment with fluoridated dentifrice, the data showed that higher \%reh was found compared to the non-fluoridated dentifrice, and professional prophylaxis was not efficient to increase rehardening. The process of loss and gain of minerals is essentially physicochemical and fluoride may effectively reduce demineralization and/or enhance rehardening ${ }^{7}$. In fact, the results of this study showed the ability of the fluoridated dentifrice to enhance the salivary properties of enamel rehardening on artificial carious lesions, regardless of the professional prophylaxis. When the enamel blocks were exposed to fluoridated dentifrice or professional prophylaxis and fluoridated dentifrice, the enamel gained mineral and the \%reh was about $20 \%$ higher than in the treatment with non-fluoridated dentifrice or non-fluoridated dentifrice and prophylaxis. Therefore, the similar percentage of remineralization found for Groups 2 and 4 probably occurred due to the presence of fluoride in the oral environment.

As regards the ability of professional prophylaxis to enhance enamel rehardening, the data clearly show that it was efficient when the non-fluoridated dentifrice was used. The hardness of the carious lesions treated with nonfluoridated dentifrice and prophylaxis was about $11 \%$ higher than the treatment with non-fluoridated dentifrice, with a statistically significant difference. In the absence of fluoride, the mechanical removal of plaque by prophylaxis improved the oral environment and increased the rehardening process. In addition, a previous study conducted by Lanza ${ }^{15}$ (2000) revealed a decrease in the salivary levels of Streptococci mutans after professional prophylaxis with air polishing for a period of 30 days. These results are in agreement with the "ecological plaque hypothesis" ${ }^{17}$, which believes in a direct relationship between the environment, the balance and the behavior of the dental plaque microbiota, and with the reports of Cury $^{6}$ (2001), who highlighted the importance of removal and/or disorganization of dental plaque for caries control.

The data of this study showed that professional prophylaxis with air polishing significantly enhanced the ability of the non-fluoridated dentifrice to increase the enamel rehardening, probably due to the favorable interference on the oral environment, did not have an additional effect on the groups that made use of the fluoridated dentifrice.

Thus, emphasis on the mechanical removal of dental plaque may be fundamental in health programs targeted to caries control, considering the increases in the levels of fluorosis, even in communities that do not have fluoridation of the public water supply ${ }^{13}$, probably because of the mass increase in the utilization of fluoridated dentifrices.

Therefore, this study meets the assumption that the adoption of preventive programs directed to mechanical plaque control and health education should be encouraged, since they comprise effective procedures for dental caries prevention.

\section{ACKNOWLEDGEMENTS}

The authors thank the volunteers who participated in the study and Prof. Dr. Jaime Aparecido Cury, Piracicaba Dental School, for the donation of the dentifrices.

This study was based on a thesis submitted by the first author to Bauru Dental School, University of São Paulo, SP, Brazil, as a partial fulfillment of the requirements of the $\mathrm{PhD}$ program in Pediatric Dentistry. 


\section{REFERENCES}

1- Arends J, Schuthof J, Jongebloed G. Microhardness indentations on artificial white spot lesions. Caries Res. 1979 Sept-Oct;13(5):290-7.

2- Arends J, Schutof J, Jongebloed WG. Lesions depth and microhardness indentations on artificial white spot lesions. Caries Res. 1980 July-Aug;14(4):190-5.

3- Arends J, ten Bosch JJ. Demineralization and remineralization evaluation techniques. J Dent Res.1992 Apr;71:924-928, Special Issue.

4- Cancro LP, Fischman SL. The expected effect on oral health of dental plaque control through mechanical removal. Periodontology 2000. 1995;8:60-74

5- Christersson LA, Zambon JJ, Genco RJ. Dental bacterial plaques. Nature and role in periodontal diseases. J Clin Periodontol. 1991 July;18:312-6.

6- CURY JA. Uso do flúor e controle da cárie como doença. In: Baratieri LN, et al. Odontologia restauradora: fundamentos e possibilidades. São Paulo, Ed. Santos; 2001. p.33-68.

7- Cury JA, Hashizume LN, Del Bel Cury AA, Tabchoury CP. Effect of dentifrice containing fluoride and/or baking soda on enamel demineralization/ remineralization: an in situ study. Caries Res. 2001 Mar-Apr;35(2):106-10.

8- Cury JA, Rebello MAB, Del Bel Cury A A. In situ relationship between sucrose exposure and the composition of dental plaque. Caries Res. 1997 Sept-Oct;31(5):356-60.

9- Dobson AJ. An introduction to statistical modelling. 2.ed. Londres, Chapman \& Hall; 1990.

10 - Featherstone JDB, ten Cate JM, Shariati M, Arends J. Comparison of artificial caries-like lesions by quantitative microradiography and microhardness profiles. Caries Res.1983 Sept-Oct;17(5):385-91.

11- Featherstone JDB, Zero DT. An in situ model for simultaneous assesment of inhibition of demineralization and enhancement of remineralization. J Dent Res. 1992 Apr;71:804-10. Special issue.

12 - Fejerskov, O. Concepts of dental caries and their consequences for understanding the disease. Community Dent Oral Epidem.1997 Feb;25(1):5-12.

13- Franzolin SOB, Gonçalves A, Padovani CR. Prevalência da fluorose e cárie denária em escolares de Bauru, SP, com diferentes serviços de abastecimento de água. In: Anais do Congresso Brasileiro de Saúde Coletiva 2.000 ago 28 - set 03; Salvador (Ba), trabalho 810.p.1-16

14- Gelhard TBFM, Arends J. In vivo remineralization of artificial subsurface enamel. I. Jour Biol Buccale. 1984 Jan- Feb;12(1):49-57.

15- Lanza CRM, Lima JEO; Torres AS, Machado MAAM. Effect of professional dental prophylaxis with sodium bicarbonate jet on the cariogenic microbiota. Pesq Odontol Bras. 2000;14:87-92.

16- Lenz, H. Ultrastructure of the tooth in respect of mineralization, demineralization and remineralization. Int Dent J. 1967 Dec;17(4):693-708.

17- Marsh, PD. Microbial ecology of dental plaque and its significance in health and disease. Adv Dent Res. 1994 July;8(2):263-71.

18- Ostrom CA, Koulourides T, Hickman F,McGhee JR. Microbial characterization of an experimental cariogenic plaque in man. J Dent Res. 1977 Jun;56(6):550-8.
19- ten Cate JM. Saliva, a physiological medium. Ned Tijdschr Tandheelkd 1992 Mar; 99(3):82-4.

20 - Tenuta LMA, Lima JEO, Cardoso CL, Tabchoury CPM, Cury JA. Effect of plaque accumulation and salivary factors on enamel demineralization and plaque composition in situ. Pesqui Odontol Bras. 2003 Oct-Dec;17(4):326-31.

21- von der Fehr FR. Maturation and remineralization. Adv Dent Res 1965; 3:83-95.

22- von der Fehr FR, Löe H, Theilade E. Experimental caries in man. Caries Res. 1970 Mar-Apr;4(2):131-48.

23- White DJ. Reactivity of fluoride dentifrices with artificial caries I: Effects on early lesions: F uptake, surface hardening and remineralization. Caries Res. 1987 Mar-Apr;21(2):126-40.

24- Zero DT. In situ caries models. Adv Dent Res.1995 Nov;9(3):21430 . 